\title{
Piotr Szczepański \\ Zrozumieć miasto. Hermeneutyka jako metoda badania fenomenu współczesnego miasta
}

\begin{abstract}
Szczepański Piotr, Zrozumieć miasto. Hermeneutyka jako metoda badania fenomenu współczesnego miasta [Understanding the city. Hermeneutics as a method to study the phenomenon of the modern city]. „Przestrzenie Teorii” 30. Poznań 2018, Adam Mickiewicz University Press, pp. 247-258. ISSN 1644-6763. DOI 10.14746/pt.2018.30.12.

In this article, the author presents the hermeneutic perspective of research in urban studies ('hermeneutics of the city') carried out within the field of cultural urban studies. 'Hermeneutics of the city' is still an unrealized project within the spatial turn in cultural studies. It is necessary to review and systematize the existing positions that make up the 'hermeneutics of the city' and outline its frameworks as theory.
\end{abstract}

KEYWORDS: hermeneutics, city, spatial turn, space, understanding, cultural urban studies

\section{Wprowadzenie}

Naukowcy podejmują coraz liczniejsze próby zrozumienia fenomenu współczesnego miasta (w tym nazwania i opisania nowych zjawisk i praktyk miejskich ${ }^{1}$ ) już nie tylko na gruncie nauk przyrodniczych, technicznych czy geograficznych ${ }^{2}$, ale też na gruncie mnożących się subdyscyplin nauk humanistycznych. Wynikają one z nasilającego się w ostatnich latach zainteresowania problematyką miejską (między innymi urbanistyka, kulturami miejskimi, sztuką w mieście, architektura, estetyką przestrzeni publicznej, polityką kulturową miast, ekologią miejska, żeby wymienić tylko najważniejsze). Wzrost zainteresowania miastem jest spowodowany również niezwykle dynamicznym rozwojem samych metropolii (,umiastowienie” swiata). Jego przyczyn można się doszukiwać w konieczności przewidywania możliwych skutków rozwoju, zmieniającej się niemal z dnia na dzień globalnej sieci powiązań ekonomicznych, kulturowych i politycznych między coraz większymi i coraz liczniejszymi ośrodkami miejskimi (powiązania te mają często charakter opozycyjny, na przykład lokalne vs globalne, prywatne vs publiczne, stare vs nowe, bogate vs biedne, silne vs słabe itd.) $)^{3}$. Obserwacje

${ }^{1}$ Zob. D. Stevenson, Cities and Urban Cultures, Philadelphia 2003.

${ }^{2}$ Zob. M. Madurowicz, Ciagtość miasta. Prolegomena, Warszawa 2017.

${ }^{3}$ Zob. Global Networks, Linked Cities, ed. S. Sassen, London-New York 2002. 
poczynione przez antropologów, kulturoznawców i filozofów zajmujących się tematyką miejską stanęły u podstaw tak zwanego „zwrotu przestrzennego" (spatial turn) w studiach kulturowych, którego początek przypada na lata siedemdziesiąte XX wieku ${ }^{4}$. „Myślenie przestrzenią” zaczęło stopniowo wypierać myślenie zorientowane historycznie - „myślenie czasem”. „Zwrot” okazał się propozycją spojrzenia na fenomen współczesnego miasta (ale też na jego historię!) z innej niż dotychczas perspektywy i umożliwił postawienie miastu zupełnie nowych pytań. Hermeneutyka filozoficzna jako jedna z wielu dyscyplin humanistycznych znalazła dla siebie nowy przedmiot zainteresowania. Byt, jakim jest współczesne miasto, ma zatem szansę, w całej swej złożoności, stać się na równi z innymi tworami (tekstami) kultury przedmiotem interpretacji ${ }^{5}$. Pozostaje tylko pytanie: czy trzeba w związku z tym tworzyć całkiem nowa teorię, jeśli zmienia się lub poszerza obszar naszych badań, czy może raczej należałoby zmodyfikować istniejące w ramach starych teorii metody?

Jednym z celów niniejszej pracy jest próba udzielenia odpowiedzi na pytanie, czy i jak miasto może stać się przedmiotem systematycznych badań hermeneutyki (poprzez „hermeneutykę” będę miał tu na myśli hermeneutykę sensu largo, czyli hermeneutykę filozoficzna), a jeśli tak, to jakie warunki muszą zostać spełnione, aby uprawnione stało się mówienie o „hermeneutyce miasta"6. Odpowiedzi na to ostatnie pytanie należy szukać, jak sądzę, w skutkach „zwrotu przestrzennego”, który zmienił dotychczasowy sposób myślenia o mieście i znaczeniu przestrzeni w badaniach kulturowych. „Hermeneutyka miasta” wydaje się bowiem wciąż niezrealizowanym projektem tego „Zwrotu” - „zwrotu”, w wyniku którego skupiono się (być może po raz pierwszy w historii nauki) na tak zwanych przestrzeniach rozumienia, przestrzeniach generujaccych znaczenia i na rozumieniu jako pewnym ruchu w przestrzeni.

\section{Zwrot przestrzenny}

Jak pisała Doris Bachmann-Medick w ksiażce Cultural Turns, stanowiacej próbę uporządkowania przemian, które zaszły w obszernym polu badań na kultura w XX i XXI wieku: „Spatial turn [zwrot przestrzenny - przyp.

${ }^{4}$ The Spatial Turn. Interdisciplinary Perspectives, eds. B. Warf, S. Arias, London-New York 2009.

${ }^{5}$ Zob. K. Szalewska, Urbanalia - miasto i jego teksty. Humanistyczne studia miejskie, Gdańsk 2017.

${ }^{6}$ Zob. Reading the City - Developing Urban Hermeneutics / Stadt lesen - Beiträge zu einer urbanen Hermeneutik, eds. N. Giersig, D. Hassenpflug, B. Stratmann, Weimar 2011; Place, Space and Hermeneutics, ed. B.B Janz, Berlin 2017; The Hieroglyphics of Space: Reading and Experiencing the Modern Metropolis, ed. N. Leach, London-New York 2002. 
PS] jest dzieckiem postmodernizmu"7. Postmodernizm zastapił rozumienie zorientowane na czas, ewolucję i historię (tak charakterystyczne dla modernizmu) rozumieniem zorientowanym na przestrzeń oraz na przestrzenny aspekt świata historycznego. Bachmann-Medick wyjaśnia:

Warto zwrócić uwagę na analogizację życia codziennego i stosowanie kategorii. Przekonuje ona nie tylko o tym, że obecne światy życia przypadają raczej na epokę przestrzeni - równoczesności i konstelacji, niż na epokę czasu - historii i ewolucji. Wnioskuje się stąd bowiem empirycznie, że w ostatnim okresie „przestrzeń” stała się nową centralną jednostką percepcji i teoretycznym konceptem ${ }^{8}$.

W przywołanym fragmencie badaczka zwraca uwagę na dwie zasadnicze zmiany, jakie zostały zaobserwowane już w latach siedemdziesiątych XX wieku: (1) żyjemy w epoce przestrzeni, co oznacza, że dominującym doświadczaniem tej epoki będzie już nie pamiętanie, wspominanie i rozwój rozumiany jako następstwo zdarzeń (chronologia), ale tymczasowość (,tuczasowość”), przygodność, przypadkowość, zerwanie ciagłości, transgresja słowem poddanie się procesom środowiskowym i zjawiskom przestrzennym, które konstytuują nasze „tu” i „teraz”; (2) przestrzeń stała się „nową centralna jednostką percepcji”. Jak to rozumieć? Już w latach sześćdziesiątych zaczęto badać między innymi oddziaływanie przestrzeni miejskiej (obrazu miasta) na człowieka oraz wpływ, jaki człowiek ma na otaczająca go przestrzeń i na innych ludzi w niej przebywających ${ }^{9}$. Ponadto „myślenie przestrzenią" jako koncept epistemologiczny zaczęło służyć wyjaśnianiu zjawisk zachodzących w świecie (przestrzeniach) władzy, pracy, nauki, sztuki, ekonomii, kultury czy wreszcie w przestrzeniach zamieszkiwania ${ }^{10}$. Przyjęcie perspektywy przestrzennej okazało się mieć również wymiar praktyczny:

$\mathrm{Na}$ pierwszy rzut oka wydaje się, iż perspektywa przestrzenna istotnie wyznacza przesiekę, która wreszcie ponownie otwiera w badaniach dojście do materialności, działania i zmiany. Przestrzeń bowiem pojmuje się tutaj nie tylko jako problem dyskursu, ile raczej jako konstrukcję społeczną ${ }^{11}$.

Przestrzeń jest zatem konstrukcją społeczną w tym sensie, w jakim stanowi materialne podłoże (przedłużenie) każdej zmiany i każdego działania

${ }^{7}$ D. Bachmann-Medick, Cultural turns. Nowe kierunki $w$ naukach o kulturze, przeł. K. Krzemieniowa, Warszawa 2012, s. 335.

8 Tamże, s. 335-336.

${ }^{9}$ Badania dotyczące percepcji i oddziaływania przestrzeni miejskiej prowadzili w latach sześćdziesiątych i siedemdziesiątych m.in. Kevin Lynch (Image of the City, 1960), Jane Jacobs (The Death and Life of Great American Cities, 1961), William H. Whyte (Street Life Project, 1969) czy Jan Gehl (Life Between Buildings: Using Public Space, 1971).

${ }^{10}$ Zob. H. Buczyńska-Garewicz, Miejsca, strony, okolice. Przyczynek do fenomenologii przestrzeni, Kraków 2006.

${ }^{11}$ D. Bachmann-Medick, dz. cyt..., s. 336. 
społecznego. Ponadto została wyposażona przez człowieka w znaczenia, ale też oddziałuje na niego bezpośrednio swoją fizycznością. Bez człowieka nie ma przestrzeni, ale też bez przestrzeni nie ma człowieka - jest to relacja zwrotna (więcej na ten temat piszę w końcowej części niniejszego artykułu). „Zwrot przestrzenny” nie wzią się znikąd. Można powiedzieć, że był on wynikiem, po pierwsze, zmian dotyczących rozwoju zachodniej cywilizacji, rozwoju technik i środków komunikacji; po drugie, rosnącego międzynarodowego obrotu kapitałem; po trzecie, rosnących międzynarodowych powiązań politycznych, ekonomicznych; po czwarte, transferu nowych, postmodernistycznych idei (wystapienia przeciw obiektywizmowi w nauce, przeciw racjonalizmowi, idei jedności, całości i systemowości). Czy istnieją jeszcze inne przyczyny „zwrotu”? Bachmann-Medick próbuje szukać jego źródła również w zjawisku globalizacji:

Usieciowienie jako cecha globalizacji sprawia, że perspektywa przestrzenna staje się nieuchronna. Kategoria czasu, powiązana z europejską ideologią ewolucyjnego rozwoju i traktowaniem go, jako historii postępu, nie potrafi już w żadnym razie uchwycić globalnych równoczesności i przestrzenno-politycznych powikłań między Pierwszym i Trzecim Światem ${ }^{12}$.

$\mathrm{Z}$ czym jeszcze wiąże się przyjęcie perspektywy przestrzennej $\mathrm{w}$ badaniach kulturowych? Jakie miejsce zajmuje przestrzeń w studiach nad kultura?? Jaką pełni funkcję? Autorka wyjaśnia:

Przestrzeń to społeczna produkcja przestrzeni jako wielowarstwowy i sprzeczny w sobie proces społeczny, jako specyficzne umiejscawianie (Verortung) kulturowych praktyk, jako dynamika relacji społecznych, niosąca w sobie możliwość przestrzennych przemian. Zwłaszcza zmiany oblicza miast i krajobrazów, dokonujące się w wyniku przestrzennego podziału pracy, pozwalają dostrzec wyraźnie, w jakiej mierze przestrzeń może być kształtowana przez kapitał, pracę, restrukturyzację ekonomiczną oraz relacje społeczne i konflikty ${ }^{13}$.

Przestrzeń kulturowa ma charakter społeczny, to znaczy jest wytwarzana społecznie. Albo inaczej: to społeczeństwo produkuje przestrzeń kulturowa. Relacje społeczne mają charakter przestrzenio- i kulturotwórczy, co oznacza, że „ukulturalniają” przestrzeń, umiejscawiając (osadzając) w niej praktyki kulturowe. Relacje zachodzące między pojedynczymi ludźmi czy grupami sa ponadto w stanie wytworzyć tak zwane miejsce. Staje się ono niemal automatycznie bytem znaczącym. Zyskuje znaczenie $\mathrm{w}$ dwojakim sensie: po pierwsze, w sensie aksjologicznym - zdobywa pewną wartość nadaną mu przez społeczność, po drugie, w sensie semantycznym - staje się symbolem (odsyła do tego, co poza nim).

12 Tamże, s. 340.

${ }^{13}$ Tamże, s. 342.

\begin{tabular}{l|l} 
Piotr Szczepański & $\mathbf{2 5 0}$
\end{tabular} 
Od zwrócenia uwagi na praktyczny charakter „zwrotu przestrzennego” dzieli nas już tylko krok do podjęcia próby rozważenia możliwości zastosowania perspektywy hermeneutycznej w badaniach nad miastem. Najpierw jednak przytoczmy stosowny fragment z Cultural Turns:

Orientowanie się w polu spacial turn nie wymaga ani wielu pojęć przestrzeni, ani samej tylko refleksji o pojęciach, ale wyraźnego stosowania perspektywy przestrzennej w wielu dyscyplinach. Decydujące jest tutaj zwrócenie się ku myśleniu o przestrzenności w analizach kulturoznawczych oraz w naukach społecznych, takie wszakże, które jednak dostarczałoby odpowiedzi na pytanie o wszelkie jego upolitycznienia i odpolitycznienia, o jego naturalizacje i symbolizacje ${ }^{14}$.

„Zwrot przestrzenny” wymaga wyraźnego stosowania perspektywy przestrzennej w znanych nam dyscyplinach naukowych, ale może też stanowić źródło powstawania nowych dyscyplin. Wydaje się, że przyjęcie perspektywy przestrzennej może zatem przysłużyć się również samej hermeneutyce, a hermeneutyka rozumieniu przestrzeni. Tym bardziej, że naukowcy badajacy i opisujacy procesy rozumienia i interpretacji, zwracaja coraz częściej swoją uwagę na zjawiska kulturowe, które konstruują przestrzeń i rzeczywistość miejska ${ }^{15}$. Co więcej, jak pisze Bachmann-Medick:

Dla spatial turn nie jest miarodajna przestrzeń terytorialna w roli kontenera lub zasobnika, ale przestrzeń jako społeczny proces produkcji spostrzegania, spożytkowywania i przyswajania, ściśle powiązany z symboliczną płaszczyzną reprezentacji przestrzennej (np. przez kody, znaki, mapy) ${ }^{16}$.

To właśnie przestrzeń rozumiana ,jako społeczny proces produkcji spostrzegania [...], ściśle powiązany z symboliczna płaszczyzną reprezentacji przestrzennej” jest mostem łączącym hermeneutykę z miastem. Silne sygnały zapowiadające spacjalizację procesów hermeneutycznych znajdujemy również w uwadze, która Bachmann-Medick wygłasza na temat metody badawczej zaproponowanej przez znanego teoretyka urbanistyki - Edwarda Soję:

Ostateczne dokonanie się zwrotu [przestrzennego - przyp. PS] następuje dopiero wtedy, kiedy zostaje poznany epistemologiczny potencjał ogniskowania przestrzennego, jak to demonstruje Soja, odwołujac się do swojej „spacjalnej hermeneutyki” (spatial hermeneutics). Proponuje on, by wszelkie akty rozumienia otwierać przestrzennie, tak by równoczesność, oboczność i rozchodzenie się nierównych sfer życia można było podobnie uchwycić, jak asymetrię podziału władzy ${ }^{17}$.

${ }_{14}$ Tamże, s. 345-346.

${ }_{15}^{5}$ Zob. Key Thinkers on Space and Place, eds. P. Hubbard, R. Kithin, London 2011; The Cybercities Reader, red. S. Graham, London-New York 2004; Thinking Space, eds. M. Crang, N. Thrift, London-New York 2003; Understanding The City. Contemporary and Future Perspectives, red. J. Eade, C. Mele, Oxford 2002.

${ }^{16}$ D. Bachmann-Medick, dz. cyt., s. 346.

17 Tamże, s. 363-464. 
„Hermeneutyka spacjalna” (HS) nie jest jednak jeszcze „hermeneutyką miasta” (HM). Ta pierwsza mówi jedynie o „uprzestrzennieniu” aktów rozumienia, a zatem mówi o samym procesie rozumienia i o tym, jak przyjęcie perspektywy przestrzennej zmienia ten proces. Można by go określić jako „poznawanie przestrzenia” lub „rozumienie przestrzenia”. HS nie mówi natomiast nic o samym przedmiocie rozumienia, czyli o treściach „do zrozumienia" oraz o generatorach tych treści, ich źródle - czyli o mieście i jego mieszkańcach.

\section{W stronę miasta}

Miasta składają się z płaszczyzn, które w mniejszym bądź większym stopniu na siebie nachodza. Wymieńmy podstawowe z nich. Sa to płaszczyzny: funkcjonalna, symboliczna i estetyczna. Ponadto, na innym poziomie, materialna warstwa miasta stanowi bazę (ramę, scenografię, podłoże) dla tego, co niematerialne (relacje międzyludzkie, strefa symboliczna, strefa wartości). Nasze spotkanie z miastem (doświadczanie miasta) odbywa się właściwie cały czas na styku i przecięciach tych płaszczyzn, warstw i stref. Ważne w tym kontekście wydają się uwagi poczynione przez Tadeusza Sławka:

[...] miasto jest wielopojawieniowe; mimo tego samego nazewnictwa i tej samej topografii nie ma „jednego” miasta. W tej sytuacji nie wolno zadowolić się ,jedna”, wizją miasta, lecz należy postrzegać je tak, jakby znajdowało się dopiero „w drodze” do siebie, niegotowe, a jego pozornie najtrwalsze konstrukcje sa w istocie najbardziej kruchymi i zwodniczymi ${ }^{18}$.

Zamieszkując, mamy zatem zawsze do czynienia z „tym samym” miastem, choć nie „takim samym”. Fizyczne miasto jest ciagle „w drodze” do siebie, a więc ciagle się staje, jest w wiecznym ruchu (problem tożsamości, trwania w czasie, problem poznania tego, co zmienne będzie tu jedynie zasygnalizowany). Ale miasto to coś jeszcze. To nie tylko obraz (stadtschaft), który chcemy zrozumieć, który się nieustannie zmienia, to nie tylko jego atmosfera, do której jesteśmy przyzwyczajeni, pozwalająca odróżnić „nasze” miasto od „innych”. Przestrzeń miejska ma charakter relacyjny, a zatem miasto to przede wszystkim sieć relacji. Wchodzimy nieustannie w relacje $\mathrm{z}$ miastem i w relacje $\mathrm{w}$ mieście. W celu lepszego zrozumienia tej kwestii przytoczę nieco dłuższy fragment tekstu Sławka, w którym autor analizuje nature tych relacji:

${ }^{18}$ T. Sławek, Miasto. Próba zrozumienia, [w:] Miasto w sztuce - sztuka miasta, red. E. Rewers, Kraków 2010, s. 20. 
[...] u podłoża naszej relacji z miastem leży pewien „zwrot”. To on wyraża sposób istnienia miasta jako specyficznego rodzaju więzi. Po pierwsze dlatego, że skoro rozumiemy miasto jako rodzaj więzi, zatem jest ono „zwrotem”, w którym „ja” dokonuje swojego umiejscowienia w stosunku do jakiegoś „ty”. W najbardziej dosłownym sensie miasto jest sposobem i stylem zwracania się ludzi nie tyle „do” siebie, co „ku” sobie. Po drugie, „zwrot” określa rodzaj zaangażowania w rzeczywistość, przy czym zaangażowanie to nosi w sobie znamiona zmiany, odmienia mój stosunek do świata [...]. Po trzecie, „zwrot” okazuje się przydatny dla nazwania zmiennego „przepływowego” charakteru miasta [...]. Miasto jest „zwrotne”, jest przestrzenia osadzoną na przegubach, łączach, i to one, a nie sztywne formacje decydują o aurze i specyfice miasta. Nie możemy jednak zapomnieć o tym - i tu znów „zwrot” pokazuje swoją użyteczność - że miasto nie tylko zawsze dysponuje, ale przede wszystkim najpierw uderza nas pewną sztywną struktura, dokładnym sformatowaniem ulic, placów i domostw. W tym sensie doświadczamy miasta zawsze pomiędzy „zwrotnością” jego przepływów a spetryfikowanymi „zwrotami”, utartymi i uładzonymi „zwrotami”, jakimi są ulice wtłoczone między rzędy kamienic. Po czwarte wreszcie, "zwrot" umieszcza miasto w sieci zobowiazzań i relacji o charakterze ekonomicznym. Przestrzeń miejska jest obszarem swoistych „zadłużeń” wymagających „zwrotu”, ale przede wszystkim - do rozważenia, czy i o ile sa to istotnie zadłużenia. Powiemy zatem, że miasto - z jednej strony - narzuca życie w sieci zadłużenia i kredytu, lecz z drugiej - o ile faktycznie jest miejscem „zwrotu” jako relacji etycznej „ja” - „ty” jest przestrzenia, w której musimy nieustannie dokonywać oceny naszego „zadłużenia”, to znaczy weryfikowania tego, czy „dług” jest w istocie niezbędną potrzeba i czy faktycznie ma spełniać nasze istotne zamierzenia ${ }^{19}$.

Miasto istniejące jako „specyficzny rodzaj więzi” to wytwór nie tylko materialny w sensie ścisłym, ale również przedmiot wyobraźni; to byt o charakterze subiektywnym i obiektywnym; to twór trwający w czasie, ale będący też przedmiotem pamięci indywidualnej i zbiorowej. Zastosowanie metody fenomenologiczno-hermeneutycznej (tj. takiej koncepcji rozumienia, która pozwala zbadać nie tylko formy i zjawiska językowe, ale również zadać pytanie o środowisko, w którym żyje, tworzy i interpretuje człowiek) może przybliżyć nas do odpowiedzi na pytanie, czym jest współczesne miasto. Przyjęcie perspektywy fenomenologiczno-hermeneutycznej pozwoli pokazać również, na jak różnych poziomach człowiek jest w stanie „przeczytać” miasto i jego „teksty”, i jak to „odczytanie” przebiega. Jednocześnie takie podejście daje szansę odpowiedzi na pytanie, jak podmiot widzi i ocenia swoje relacje przestrzenne z miastem i innymi mieszkańcami, jak rozumie swoją codzienną w mieście egzystencję. Na czym polega budowanie i interpretowanie wizerunku (krajobrazu) miasta? Czemu ta interpretacja ma służyć? Jak człowiek rozumie miasto? To kolejne pytania, nad którymi warto się pochylić.

${ }^{19}$ Tamże, s. 21-22. 


\section{W stronę "hermeneutyki miasta"}

W jakim stopniu miasto może stać się przedmiotem interpretacji? $\mathrm{Na}$ jakich zasadach? Jakie warunki muszą zostać spełnione, żeby uprawomocnione stało się mówienie o „hermeneutyce miasta”? Czy pytanie o miasto jako przedmiot hermeneutyki nie leży już w obrębie samej hermeneutyki? Co więcej, wypada ponownie zapytać - i nie sposób tego pytania pominać czym jest miasto jako takie? Jaka jest jego ontologia ${ }^{20}$ ? Czy przypadkiem nie zakładamy tu, w punkcie wyjścia, znajomości przedmiotu, którego naturę chcemy badać? Czy nie mamy już jakiegoś wcześniejszego wyobrażenia o nim, które determinuje dalsze poznanie? Dopiero udzielając odpowiedzi na powyższe pytania, można poruszyć kwestię dotyczącą tego, co nowego o współczesnym mieście może nam powiedzieć hermeneutyka.

Pytanie o status tak nietypowego przedmiotu interpretacji kieruje nasza uwagę w stronę podmiotu, który pragnie rozpocząć swoje hermeneutyczne dociekania oraz do teorii, która przyjmuje on w punkcie wyjścia, zanim zada jakiekolwiek pytanie. Spojrzenie na fenomen współczesnego miasta przez pryzmat trójkąta interpretacyjnego: podmiot - teoria - przedmiot już na samym początku nastręcza wiele trudności (z problemem „koła hermeneutycznego" włącznie). Po pierwsze, przedmiot interpretacji - miasto - jest bytem (dosłownie i w przenośni) rozciagniętym w czasie i przestrzeni, i nie da się go objąć jednym, syntezującym spojrzeniem tak, aby mieć wgląd we wszystkie mikrohistorie dziejące się aktualnie we wszystkich jego mikroprzestrzeniach. Po drugie, jest to byt podlegajacy ciagłym zmianom fizycznym, których nie sposób równocześnie doświadczyć, a co dopiero skatalogować i nazwać. Po trzecie, miasto posługuje się wieloma równoważnymi językami („komunikuje” nam siebie na wiele sposobów), z których każdy zasługuje na osobne potraktowanie. Czy oznacza to, że nie można go w ogóle poznać? Istoty i sensu miasta należy chyba szukać inaczej i gdzie indziej. Jak pisze Rafał Koschany: należy ich szukać „na różnych poziomach, w różnych miejscach i w różnych kontekstach" ${ }^{21}$. Koschany twierdzi, zresztą chyba słusznie, że nie ma jednej interpretacji, jednej metody dojścia do prawdy na temat miasta. Wiedza o mieście będzie mieć zawsze charakter wybrakowany, fragmentaryczny, niepełny.

Przestrzeń miasta jest przestrzenią sensowną (znacząca), dlatego że jest dziełem kultury. Działalność ludzka nadaje sens przestrzeni (nawet jeśli jest to działalność destrukcyjna), łatwy do odczytania jeśli tylko opanowało

\footnotetext{
${ }^{20}$ Por. E. Rewers, Post-polis. Wstęp do filozofii ponowoczesnego miasta, Kraków 2005.

${ }^{21}$ R. Koschany, Interpretacje, [w:] Kulturowe studia miejskie. Wprowadzenie, red. E. Rewers, Warszawa 2014, s. 264.
} 
się gramatykę języka, w którym owa działalność została wyrażona. Relacja kulturowa człowieka i miasta jest zatem z konieczności relacją o charakterze interpretacyjnym. Chociaż miasto jest czymś zewnętrznym w stosunku do nas, bez człowieka jego znaczenie i zrozumienie jest niemożliwe - bez człowieka nie ma miasta. Jak pisze Rafał Koschany:

A zatem - po pierwsze - interpretacja miasta to, z jednej strony, praktyka podmiotów miejskich, refleksyjnie porządkujących i scalających swoje doświadczenia, prowadzące do wykształcenia się oddolnych sposobów rozumienia miasta, z drugiej zaś, konkretne wytwory czy ślady miejskich podmiotów, refleksyjnie odnoszących się do zamieszkiwanej przez siebie przestrzeni. Po drugie, owe wytwory, rzecz jasna, prędzej czy później przyczyniaja się do ugruntowania pewnego „obrazu” miasta, stają się elementami swoistej układanki miasta jako przestrzeni interpretacyjnie wytworzonej. Miasto, tak jak je rozumiemy „na zewnątrz”, z dystansu, okazuje się wielowymiarową zróżnicowana, palimpsestową siecią interpretacji, które uzyskują wymiar intersubiektywny. Po drugiej stronie leży przekonanie, że interpretacje miast odbywają się przez pryzmat ich reprezentacji [...]. Koniecznie zatem trzeba odróżnić interpretację miasta samego (sytuacja ściśle empiryczna) od interpretacji tekstu kultury, którego „bohaterem” jest miasto ${ }^{22}$.

Interpretacja miasta zatem to nasze wszystkie codzienne, pojedyncze akty rozumienia i działania (intencjonalne i nieintencjonalne), w których ujmujemy miasto jawiące się nam bezpośrednio. Co więcej, tak rozumiana interpretacja pozwala uchwycić znaczenie miasta jako efekt wcześniejszych, licznych aktów interpretacyjnych i kumulacji znaczeń. Nowe interpretacje, powstajacce $\mathrm{w}$ wyniku relacji $\mathrm{z}$ interpretowanym przedmiotem, zmieniaja swym pojawieniem się charakter tej relacji. Innymi słowy, miasto jest dla nas zbiorem sensów, który się nieustannie zmienia. Na bazie zastanych sensów, żyjąc w mieście, tworzymy nowe, które zmieniają wyjściową zawartość zbioru. Tym samym znaczenie miasta nigdy nie daje się zamknąć w jednym tylko zestawie wartości, wrażeń, symboli czy innych ogólnych czy szczegółowych charakterystyk. Ponadto, jak pisze Koschany:

Co ważne, kolejne interpretacje, zwłaszcza te, które z różnych powodów przebijają się do świadomości potocznej oraz obiegu naukowego, przyczyniają się do umocnienia bądź zrewidowania danej reprezentacji. W ten sposób w procesie interpretacji w pewnym sensie samo miasto ulega przeobrażeniu ${ }^{23}$.

Trzeba tu pamiętać, że jednak czym innym jest ,jednostkowe przepracowanie doświadczenia przestrzeni”, a czym innym próba sformułowania „ogólnej teorii interpretacji miasta" (jeśli w ogóle możliwa). Wydaje się, że nawet zebranie sporej grupy opisów jednostkowych doświadczeń (zbiór reprezentacji

\footnotetext{
${ }^{22}$ Tamże, s. 264-265.

${ }^{23}$ Tamże, s. 265.
} 
doświadczeń miejskich) i ich zestawienie (według jakiej metody?) nie może przyczynić się do wypracowania ostatecznej, jednej, uniwersalnej hermeneutyki miasta. Czym innym będzie bowiem teoria interpretacji, a czym innym suma jednostkowych aktów interpretacji. Akt interpretacji nie zawsze jest czymś uświadomionym, czasem jest aktem spontanicznym: nie tyle ma miejsce „wbrew” woli, co jest „pomimo” woli. „Ogólna teoria interpretacji miasta” musiałaby zawierać miedzy innymi zbiór metod pozwalających na wydobycie „sensu” wszystkiego, co w mieście interpretowane, podczas gdy sam akt pozostanie niczym innym jak tylko jednostkowym, funkcjonalnym (doświadczeniowym) aspektem owych metod. Warto w tym miejscu zaznaczyć jeszcze jedną wątpliwość dotyczącą związku między interpretatorem a tym, co interpretowane:

Otóż specyfiką teorii interpretacji przestrzeni człowieka, w tym chodzi również o tak konkretna przestrzeń jak miasto, jest swoiste skażenie interpretującego podmiotu doświadczeniem interpretowanej przestrzeni. [...].

W rzeczywistości zatem interpretacja dotyczy - w równym stopniu - zarówno interpretującego podmiotu, jak i przedmiotu interpretowanego, czyli miejsca, z którego wydobywa się interpretacja. [...]. W przypadku interpretacji miasta, a więc w sytuacji, kiedy interpretujacy podmiot jest jednocześnie podmiotem zanurzonym w żywioł interpretowanej przestrzeni, dochodzi zatem do swoistego osłabienia pojęcia interpretacji ${ }^{24}$.

Takim zanurzeniem $\mathrm{w}$ interpretowaną przestrzeń, które jest jednocześnie oddziaływaniem na nia, kształtowaniem owej przestrzeni, jest „zamieszkiwanie", o którym szerzej pisze Martin Heidegger ${ }^{25}$. Zamieszkiwanie jest formą egzystowania podmiotu w mieście, formą oswajania przestrzeni poprzez jednoczesne, ciagłe poddawanie jej zabiegom interpretacyjnym, modyfikującym ostatecznie samo zamieszkiwanie. Przestrzeń i interpretacja zyskują tu wymiar autobiograficzny. Tę zwrotność dobrze tłumaczy w jednym ze swoich tekstów Hanna Buczyńska-Garewicz: „Z jednej strony, myślenie prawdy bycia na nowo określa przestrzeń, z drugiej zaś, język przestrzeni staje się istotny dla nowego sposobu myślenia o byciu" ${ }^{\prime 26}$.

\section{Podsumowanie}

Jak dotąd nikt nie podjął próby stworzenie „ogólnej teorii interpretacji miasta". Dotychczasowe związki hermeneutyki i polis polegały najczęściej na fragmentarycznym adaptowaniu wybranych elementów teorii klasyków

${ }^{24}$ Tamże, s. 285-286.

${ }^{25}$ M. Heidegger, Budować, mieszkać, myśleć, [w:] tegoż, Odczyty i rozprawy, przeł. J. Mizera, Warszawa 2002; por. J. Malpas, Heidegger and the Thinking of Place. Explorations in the Topology of Being, Cambridge 2012.

${ }^{26}$ H. Buczyńska-Garewicz, dz. cyt., s. 86. 
dwudziestowiecznej hermeneutyki na potrzeby badań określonych miejskich zjawisk czy wybranych zagadnień związanych z doświadczaniem miejsca i przestrzeni, będących jednocześnie próbą opisania i wyjaśnienia natury ludzkiego bycia-w-świecie ${ }^{27}$. Hermeneutyka jeszcze do niedawna niechętnie zajmowała się miastem. Być może działo się tak dlatego, że przedmiot interpretacji - wydawałoby się, tak dobrze wszystkim znany - nie ma wyłącznie tekstowego charakteru i jest zbyt złożony, żeby próbować przykładać do niego narzędzia jednej tylko teorii. Aczkolwiek wiele wskazuje na to, że hermeneutyka miasta ma szansę stać się ważną częścią kulturowych studiów miejskich (czekająca jednak wciąż na pogłębione opracowanie).

Miasto odsłania swoje sensy powoli, w wielu interpretacjach, ponieważ mówi wieloma językami, ponieważ stanowi nałożenie na siebie wielu warstw znaczeniowych, obrazów, tekstów, dyskursów, a także subiektywnych interpretacji, wynikających z jednostkowych doświadczeń. Droga do zrozumienia miasta (tego, co w nim materialne i niematerialne) wydaje się biec nie tylko przez drobiazgową analizę miejskich fenomenów i kultur, ale też przez analizę aktów interpretacyjnych podmiotu, który poddaje interpretacji świat, w którym żyje. Aby zrozumieć miasto, trzeba zrozumieć siebie, ale też, aby zrozumieć siebie - trzeba zrozumieć zajmowane przez siebie miejsce, tj. przestrzeń i środowisko naszego zamieszkiwania. Można powiedzieć, parafrazując słynne stwierdzenie Siegfrieda Lenza dotyczące związku człowieka z krajobrazem, że miasta i ich znaczenia powstają przez nas ${ }^{28}$.

\section{BIBLIOGRAFIA}

Bachmann-Medick D., Cultural turns. Nowe kierunki w naukach o kulturze, przeł.

K. Krzemieniowa, Warszawa 2012.

Buczyńska-Garewicz H., Miejsca, strony, okolice. Przyczynek do fenomenologii przestrzeni, Kraków 2006.

Gehl J., Życie między budynkami. Użytkowanie przestrzeni publicznych, przeł. M.A. Urbańska, Kraków 2013.

Global Networks, Linked Cities, ed. S. Sassen, London-New York 2002.

Heidegger M., Budować, mieszkać, myśleć, [w:] M. Heidegger, Odczyty i rozprawy, przeł.

J. Mizera, Warszawa 2002.

Jacobs J., Śmierć i życie wielkich miast Ameryki, przeł. Ł. Mojsak, Warszawa 2014.

Key Thinkers on Space and Place, eds. P. Hubbard, R. Kithin, London 2011.

Kulturowe studia miejskie. Wprowadzenie, red. E. Rewers, Warszawa 2014.

${ }^{27}$ Zob. Place, Space and Hermeneutics...

${ }^{28}$ S. Lenz, Wptyw krajobrazu (landszaftu) na człowieka, przeł. Z. Kadłubek, [w:] Miasto w sztuce-sztuka miasta, red. E. Rewers, Kraków 2010, s. 71. 
Lenz S., Wpływ krajobrazu (landszaftu) na człowieka, przeł. Z. Kadłubek, [w:] Miasto w sztuce - sztuka miasta, red. E. Rewers, Kraków 2010.

Lynch K., Obraz miasta, przeł. T. Jeleński, Węgrzce 2011.

Madurowicz M., Ciagtość miasta. Prolegomena, Warszawa 2017.

Malpas J., Heidegger and the Thinking of Place. Explorations in the Topology of Being, Cambridge 2012.

Miasto w sztuce - sztuka miasta, red. E. Rewers, Kraków 2010.

Pisanie miasta - czytanie miasta, red. A. Zeidler-Janiszewska, Poznań 1997.

Place, Space and Hermeneutics, ed. B.B. Janz, Berlin 2017.

Reading the City - Developing Urban Hermeneutics / Stadt lesen - Beiträge zu einer urbanen Hermeneutik, eds. N. Giersig, D. Hassenpflug, B. Stratmann, Weimar 2011.

Rewers E., Post-polis. Wstę do filozofii ponowoczesnego miasta, Kraków 2005.

Rosner K., Heremeneutyka jako krytyka kultury, Warszawa 1991.

Stevenson D., Cities and Urban Cultures, Philadelphia 2003.

Szalewska K., Urbanalia - miasto $i$ jego teksty. Humanistyczne studia miejskie, Gdańsk 2017.

The Cybercities Reader, ed. S. Graham, London-New York 2004.

The Hieroglyphics of Space: Reading and Experiencing the Modern Metropolis, red. N. Leach, London-New York 2002.

The Spatial Turn. Interdisciplinary Perspectives, eds. B. Warf, S. Arias, London-New York 2009.

Thinking space, eds. M. Crang, N. Thrift, London-New York 2003.

Understanding the City. Contemporary and Future Perspectives, eds. J. Eade, C. Mele, Oxford 2002. 